\title{
Maize yield in an integrated crop-livestock-forestry system in south Goiás, Brazil ${ }^{1}$
}

\author{
Flávia Feliciano Da Costa Silva², Jorge Luís Sousa Ferreira ${ }^{2 *}$ (D), Tatiana Vieira Ramos ${ }^{3}$, Francine Neves Calil ${ }^{4}$
}

10.1590/0034-737X202067030002

\begin{abstract}
Cerrado biome is responsible for part of Brazilian food production. However, due to inadequate soil management practices, large areas of crop and forage are degraded, leading to environmental and economic losses. A crop-livestock-forest system (CLFS) is a sustainable production strategy that integrates different cultivations. This objective of this study was to evaluate agronomic characteristics and maize (Zea mayz L.) yield when consorciated with Panicum maximum cv. Tamani, cultivated between rows of eucalypts clones. The statistical design used was randomized blocks, constituted by the following treatments: Maize + AEC 043; Maize + AEC 007; Maize + AEC 2111; and Maize + AEC 2034. The analyzed variables included: spikes length, number of rows, number of grains per row, number of grains per spike, and grain yield. Based on the obtained data, it is possible to conclude that trees did not affect maize yield in a CLFS. Considering that only $60 \%$ of the area was used for agriculture, maize yield was higher than when it is planted in total area.
\end{abstract}

Keywords: consortium; grains yield; integrated systems; Zea mays L.

\section{INTRODUCTION}

Integrated crop-livestock systems have been identified as an alternative to achieve these objectives, sustainability, and development of the rural sector. This involves the cultivation of annual crops and grazing livestock production, aiming to generate positive socioeconomic and environmental results. These advantages are made possible by the successive and continuous use of the areas, the increase of agricultural and livestock yields, and the reduction of production costs, provided by the chemical, physical, and biological improvements of the soil (Franzluebbers, 2007; Conte et al., 2011).

Several studies suggest that integrated systems such as crop-livestock-forest systems (CLFS), when wellmanaged, improve some of the soil properties, such as physical structure and fertility, and may contribute to the increase of total soil organic carbon stocks (Souza et al., 2009; Silva et al., 2011; Silva et al., 2014).
Currently, Brazil has 11.5 million hectares with integrated agricultural production systems; the State of Goiás and the Federal District contribute almost 950 thousand hectares. The studies also indicate that the states of Mato Grosso do Sul, Mato Grosso, and Rio Grande do Sul were the ones that most increased the areas with CLFS. The system can be used in different configurations, combining two or three components. Among the four possibilities of different productive systems, the agropastoral system (Integrated CropLivestock-Forest) is the most adopted by the producers (REDE FOMENTO ILPF, 2016).

The forage-maize consortium contributes to the improvement of soil properties, increasing nutrient cycling, organic matter content, and fertility by means of high organic matter production and high root volume (Crusciol \& Borghi, 2007; Calonego et al., 2011). The intensification of the production observed in the integrated croplivestock-forest system (CLFS) can cause the following:

\footnotetext{
Submitted on December 17 th, 2018 and accepted on April $30^{\text {th }}, 2020$.

${ }^{1}$ Master's Dissertation of the first author.

${ }^{2}$ Universidade Federal de Goiás, Programa de Pós-Graduação em Agronomia, Goiânia, Goiás, Brazil. flaviafelicianoagro@yahoo.com.br; jorgeluisferreira89@hotmail.com

${ }^{3}$ Universidade Estadual de Goiás, Ipameri, Goiás, Brazil. tatiana.v.ramos@hotmail.com

${ }^{4}$ Universidade Federal de Goiás, Goiânia, Goiás, Brazil. fncalil@gmail.com

*Corresponding author: jorgeluisferreira89@hotmail.com
}

Rev. Ceres, Viçosa, v. 67, n.3, p. 176-180, may/jun, 2020 
improves the physical, chemical, and biological conditions of the soil; increases cycling and nutrient utilization efficiency; reduces production costs; diversifies and stabilizes income on rural property; and enables the recovery of areas with degraded pastures (Alvarenga et al., 2010).

In a study carried out from 1997 to 2008 in CLFS with different cultivation systems, concluded that maize was the most efficient in energy conversion in comparison with other treatments (Santos et al., 2013).

According to data from the Companhia Nacional de Abastecimento (CONAB, 2017), sowing of maize grown in the first crop of 2016 occurred in a total area of 5.48 million hectares, producing 30.46 million tons and an increase of $18.3 \%$ in relation to the previous harvest.

Knowledge of how annual crop, forage, and trees are affected in a consortium is of fundamental importance for successful training and/or renewal of pasture and satisfactory crop production. However, studies on planting arrangements and the influence of integrated systems on component productivity are scarce. Thus, the objective of this study was to evaluate agronomic characteristics and maize (Zea mayz L.) yield when consorciated with Panicum maximum cv. Tamani, cultivated between rows of eucalypts clones in the Integrated Crop-Livestock-Forest system (CLFS) in an area located in the southern region of the State of Goiás.

\section{MATERIAL AND METHODS}

The study was conducted during the agricultural year of 2016/2017 in Inaciolândia, Goiás. The experimental area is located at $18^{\circ} 32^{\prime} \mathrm{S}$ and $49^{\circ} 48^{\prime} \mathrm{W}$ at $459 \mathrm{~m}$ altitude. According to the classification of Köppen-Geiger, the predominant climate in the region is the type Aw - tropical climate with dry winter season (Cardoso et al., 2014). The average annual rainfall is $1400 \mathrm{~mm}$, concentrated in the rainy season from October to March. As for rainfall distribution, the highest volume occurs in January, presenting an average of $271 \mathrm{~mm}$, and June is the driest month, having only $10 \mathrm{~mm}$. The average annual temperature is $24.8^{\circ} \mathrm{C}$, registering a maximum of $26.2^{\circ} \mathrm{C}$ in September, while the lowest is $22.1^{\circ} \mathrm{C}$ in June (ClimateData, 2017).

The soil is classified as Latosols with horizon "A" predominate, moderately and prominently of very clay like texture (Embrapa, 1999).

By the year 2015, the area was used for the cultivation of soybean (Glycine max L.) in a conventional system. In the year of 2016, the Integrated Crop-Livestock-Forest system (CLFS) was adopted in approximately 40 hectares. For the establishment of the system, eucalyptus clones were implanted, and later, a forage species Panicum maximum cv. Tamani was intercropped with maize (Zea mays L.).

Four eucalyptus clones were planted separately, denominated AEC 2034 (Eucalyptus camaldulensis x E. grandis) and E. urophylla)), AEC 2111 (E. urophylla x (E. camaldulensis x E. grandis)), AEC 007 (E. toreliana $\mathrm{x} E$. citriodora), and AEC 043 (E. citriodora x E. toreliana). For the spatial arrangement of the eucalyptus, the planting in rows, each with four rows, was spaced $3.0 \mathrm{~m} \times 2.5 \mathrm{~m}$. The distance used between rows was $24 \mathrm{~m}$, totaling 38 rows. The nurseries were oriented east-west to allow for greater insolation to the cultures intercropped between the rows.

The experimental design was a randomized block design. For the constitution of the experimental area, 16 rows were used, where each plot was represented by a row of eucalyptus with maize. Each clone consisted of four replicates (blocks).

The area occupied by trees correspond to $34,0 \%$ of the total area, and $66,0 \%$ of the area was used for maize cultivation. For maize productivity calculation, it was considered only the effective planted area.

For the planting of the seedlings of the eucalyptus clones, ant and termite control was carried out in the whole area. After that, the grouting (monohaste subsurface) was performed in the planting line at $60 \mathrm{~cm}$ depth, and then, there was application of $300 \mathrm{~kg} \mathrm{ha}^{-1}$ of Mono-AmmoniumPhosphate (MAP) in formulation of 11-52-00 (N-P $\left.\mathrm{O}_{5}-\mathrm{K}_{2} \mathrm{O}\right)$. Cover fertilization was carried out in May 2016 after establishment of the seedlings, using $120 \mathrm{~g}$ of 20-00-20 $\left(\mathrm{N}-\mathrm{P}_{2} \mathrm{O}_{5}-\mathrm{K}_{2} \mathrm{O}\right)$ per plant.

At the time of maize and pasture sowing, the eucalyptus was eight months old and had an average height of $2.5 \mathrm{~m}$. Maize was planted in November 2016 in the Santa Fé System, which includes maize and Tamani (Panicum maximum) crops planted together, using a mechanized planting planter for intercropping with two maize lines spaced $0.90 \mathrm{~m}$, interspersed at $0.90 \mathrm{~m}$ with grass.

Seeding was carried out while keeping a minimum distance of $1.0 \mathrm{~m}$ from the eucalyptus in order to minimize the initial competition among the species. Planting and cover fertilization consisted of $350 \mathrm{~kg} \mathrm{ha}^{-1}$ of formulated fertilizer 08-28-16 (N-P $\left.\mathrm{O}_{5}-\mathrm{K}_{2} \mathrm{O}\right)$ and $200 \mathrm{~kg} \mathrm{ha}^{-1}$ of $45 \% \mathrm{~N}$ urea (divided into two applications), respectively. All the cultural and silvicultural treatments necessary for each crop were carried out, respecting their individual technical recommendations.

After one year and two months of eucalyptus planting, cattle were introduced into the integrated system.

The evaluations of the agronomic characteristics of maize were carried out approximately 165 days after sowing. The material was collected randomly in each block, where nine spikes were collected manually per block, 
totaling 36 spikes per treatment, in this case the eucalyptus clones. In Table 1 it is possible to verify the average height (m) and DBH (cm) for all clones at the harvesting time.

The collected spikes were taken to the laboratory and placed in the open air for drying. After 10 days of drying, the variables: number of rows per spike (NRS), number of grains per row (NGR) and number of grains per spike (NGS) were quantified by visual counting.

After this evaluation, the spikes were shucked, and it was verified if the grains were humidity up to $15 \%$, using a digital humidity meter Motomco 999ES. This check is important, so that the grains do not suffer from the action of pathogens that rot them, due to the high humidity during the storage. Then, the grains were weighed using a precision scale, generating a mean, which in turn was multiplied by the number of plants per useful plot to determine the productivity of each the treatments, expressed in $\mathrm{kg} \mathrm{ha}^{-1}$ and then converted to bags ha-1, when one bag equals to $60 \mathrm{~kg}$.

Also, based on the 36 spikes sampled per treatment, the value of total spike length (SL) was measured, along with the aid of a graded scale.

The sample results were submitted to analysis of variance, accompanied by means tests by the Tukey test at $5 \%$ of probability, using the statistical program SISVAR®.

\section{RESULTS AND DISCUSSION}

The results regarding the analyses of variance of the agronomic characteristics of the maize (Table 2) indicated

Table 1: Average height $(\mathrm{m})$ and $\mathrm{DBH}(\mathrm{cm})$ for all clones at the maize harvesting time

\begin{tabular}{lcc}
\hline \multirow{2}{*}{ Clones } & \multicolumn{2}{c}{ 13 months } \\
\cline { 2 - 3 } & Height $(\mathbf{m})$ & DBH $(\mathbf{c m})$ \\
\hline AEC-2034 & $7,03 \mathrm{a}$ & $7,01 \mathrm{a}$ \\
AEC-2111 & $5,73 \mathrm{~b}$ & $5,62 \mathrm{~b}$ \\
AEC-043 & $6,24 \mathrm{~b}$ & $5,24 \mathrm{~b}$ \\
AEC-007 & $4,20 \mathrm{c}$ & $3,17 \mathrm{c}$ \\
\hline
\end{tabular}

DBH $=$ Diameter at Breast Height $(1,30 \mathrm{~m})$ a significant effect of the clones for maize spike length, number of grains per row, and number of grains per spike. No significant differences ( $p>0.05$ ) were observed for the number of rows of grain per spike.

One of the main production components in the definition of maize yield is the spike length. According to Ohland (2005), the maize spike length, maize spike diameter, number of spikes per area, and grain density are characteristics that, together with the genotype, determine the productivity potential.

The length of the spikes ranged from 15.09 to $17.32 \mathrm{~cm}$ in the treatment with clones AEC 043 and AEC 2034, respectively. Higher results were observed by Ohland (2005) who, working with predecessor crops for maize, obtained average spike length values on the order of 19.50 $\mathrm{cm}$.

The number of grains per row in the spikes varied in the maize consortium with the different eucalyptus clones. The highest value observed was in the treatment with AEC 2034, whose number of grains per row was 39.30. According to Fancelli \& Dourado Neto (2000) and Gimenes et al. (2008), the photo assimilates of the leaves, once produced, are translocated to the stem of the plant, which are storage structures of soluble solids. The larger its diameter consequently results in greater storage capacity of photo assimilates, which contributes grain formation.

According to Didonet et al. (2002), the potential number of grains per spike is determined when the plants reach 10 to 12 fully developed leaves, long before the tasseling. During this period, assuming sufficient water and no nutritional deficiencies, the main factors that determine the number of grains and the yield of maize are the air temperature and the global solar radiation incidence until flowering and/or furrowing.

In analyzing the number of grains per maize spike in the present study, it was observed that the maize consortium with clone AEC 2034 produced spikes with 86.5 grains, which was $16 \%$ more than in the consortium with AEC 2111. The development of maize grain (from filling to maturation) is completed on average 50 to 60 days after

Table 2: Mean values of agronomic characteristics for maize (Zea mays L.)

\begin{tabular}{|c|c|c|c|c|}
\hline Treatment & $\begin{array}{l}\text { Maize spike } \\
\text { length }(\mathrm{cm})\end{array}$ & $\begin{array}{l}\text { Number } \\
\text { of rows }\end{array}$ & $\begin{array}{l}\text { Number of grains } \\
\text { per row per spike }\end{array}$ & $\begin{array}{c}\text { Number of grains } \\
\text { per spike }\end{array}$ \\
\hline Milho + AEC 043 & $15.09 \mathrm{~b}$ & $13.27 \mathrm{a}$ & $33.41 \mathrm{~b}$ & $448.61 \mathrm{bc}$ \\
\hline Milho + AEC 007 & $16.53 \mathrm{a}$ & $13.72 \mathrm{a}$ & $36.13 \mathrm{ab}$ & $493.44 \mathrm{ab}$ \\
\hline Milho + AEC 2111 & $15.13 \mathrm{~b}$ & $13.27 \mathrm{a}$ & $33.16 \mathrm{~b}$ & $438.72 \mathrm{c}$ \\
\hline Milho + AEC 2034 & $17.32 \mathrm{a}$ & $13.33 \mathrm{a}$ & $39.30 \mathrm{a}$ & $525.22 \mathrm{a}$ \\
\hline $\mathrm{CV}(\%)$ & 12.98 & 9.16 & 15.37 & 17.57 \\
\hline$P$ value & 0.00 & 0.35 & 0.00 & 0.00 \\
\hline $\mathrm{S}_{\mathrm{x}}$ & 0,34 & 0,20 & 0,90 & 13,95 \\
\hline
\end{tabular}

Means followed by the same letter in the columns did not differ by Tukey test $(\mathrm{p}<0.05) . \mathrm{S}_{\mathrm{x}}=$ standart error.

Rev. Ceres, Viçosa, v. 67, n.3, p. 176-180, may/jun, 2020 
fertilization. Shade conditions or cloudy periods may influence the reduction of photosynthesis, which increases the plant's stress level and implies the reduction of the dry mass accumulation rate of the grain in addition to consequent reduction in the final grain yield (Fancelli \& Dourado Neto, 2000).

The average values for the number of rows of grain per spike did not present significant difference among the treatments. In other words, the management systems did not influence this variable. Similar results were obtained by Costa et al. (2012) and Freitas et al. (2013), and this result emphasizes the conclusion that the number of rows of grain per spike is largely controlled by genetics and is not greatly influenced by external factors. The averages varied from 13.27 to 13.72 rows of grains per spike, for the treatments AEC 043 and AEC 2111.

Feitosa et al. (2016), working with intervals between 30 and $42 \mathrm{~m}$, did not observe the interaction effect of the distances between the rows on the agronomic characteristics of maize (length of spikes, diameter of spikes, number of grains per row and number of rows per spike). This may be due to the smaller interspecific competition that occurs in this configuration of CLFS, in which there is a greater supply of resources to the maize crop compared to eucalyptus.

The grain yield variable showed a significant difference $(p<0.05)$ as a function of the consortium (Table 3).

The average yield of the four treatments was $5675 \mathrm{~kg}$ $\mathrm{ha}^{-1}$, which is higher than the national average of $5490 \mathrm{~kg}$ $\mathrm{ha}^{-1}$. However, the national average is that of maize grown as a monoculture (CONAB, 2017).

When evaluating the productivity of the systems, it was observed that the maize consortium with clone AEC 2034 differed statistically from the others, especially in grain production. In general, maize yield values reached by treatments were similar to the average of the monoculture system obtained by CONAB (2017). This

Table 3: Productivity of maize (Zea mays $L$.) as a function of the consortium with different eucalyptus clones

\begin{tabular}{lrr}
\hline \multirow{2}{*}{ Treatments } & \multicolumn{2}{c}{ Productivity } \\
\cline { 2 - 3 } & kg ha $^{-1}$ & bag ha $^{-1}$ \\
\hline Maize + AEC 043 & $5.293 .16 \mathrm{~b}$ & $88.21 \mathrm{~b}$ \\
Maize + AEC 007 & $5.625 .26 \mathrm{~b}$ & $93.75 \mathrm{~b}$ \\
Maize + AEC 2111 & $5.226 .49 \mathrm{~b}$ & $87.10 \mathrm{~b}$ \\
Maize + AEC 2034 & $6.556 .34 \mathrm{a}$ & $109.27 \mathrm{a}$ \\
\hline CV $(\%)$ & \multicolumn{2}{c}{17.53} \\
$P$ value & 0.00 \\
$\mathrm{~S}_{\mathrm{x}}$ & \multicolumn{2}{c}{165,78} \\
\hline Means followed by the same letter in the columns did not differ by \\
Tukey test (p<0.05). $\mathrm{S}_{\mathrm{x}}=$ standart error. One bag equal to 60 kg of \\
maize.
\end{tabular}

suggests that there is no negative interaction between the tree component and the agricultural component, considering the initial stage of development of the tree component.

These results can be explained by the use of wider plant spacing of the eucalyptus, allowing for a greater incidence of light between the rows.

Porfirio-da-Silva et al. (2015) did not observe an effect of eucalyptus shading on yield of maize grown in the $14 \mathrm{x}$ $3 \mathrm{~m}$ arrangement in the Campos Gerais region (PR), which presented an average grain yield of $4250 \mathrm{~kg} \mathrm{ha}^{-1}$ in the single system and $4550 \mathrm{~kg} \mathrm{ha}^{-1}$ in a silvicultural system. In another study by Simão et al. (2012) in Sete Lagoas-MG, the authors concluded that when eucalyptus planting is simultaneous to maize sowing and forage in Santa Fé System, grain and fodder productivity were not affected by eucalyptus competition.

Wendling et al. (2014) obtained average grain yield of $3502.1 \mathrm{~kg} \mathrm{ha}^{-1}$ for maize intercropped with different pastures. The spacing adopted by these authors was $15 \mathrm{x}$ $2.0 \mathrm{~m}$, and sowing of the maize with the pasture was performed when the eucalyptus rows that had a mean height of $11.36 \mathrm{~m}$.

In general, cereals suffer from shading, but certain advantages can be observed, such as the increase of humidity provided by wind protection in dry climatic conditions (Kuemmel, 2003).

The integrated production system in question, even though it does not provide a total area for the production of the agricultural crop, achieves an average productivity higher than that of the monoculture areas, considering CONAB's data (2017). However, it assists in sustainable soil management, seeking to intercrop or rotate crops in the same area.

\section{CONCLUSIONS}

The tree component did not present a negatively influence on maize productivity in the ILPF system. Cultivated in $66 \%$ of agricultural area, maize yield was higher than when grown in total area.

\section{ACKNOWLEDGEMENTS, FINANCIAL SUPPORT AND FULL DISCLOSURE}

The authors thank to the owner of the farm (Dr. Abílio Rodrigues Pacheco) for all support during the experiment time. The same authors declare than there is not conflict of interest.

\section{REFERENCES}

Alvarenga RC, Silva VP DA, Gontijo Neto MM, Viana MCM \& Vilela L (2010) Sistema Integração Lavoura-Pecuária-Floresta: Condicionamento do solo e intensificação da produção de lavouras. Informe Agropecuário, 31:59-67. 
Calonego JC, Poleto LC, Domingues FN \& Tiritan CS (2011) Produtividade e crescimento de milho em diferentes arranjos de plantas. Revista Agrarian, 4:84-90.

Cardoso MRD, Marcuzzo FFN \& Barros JR (2014) Classificação climática de KÖPPEN-GEIGER para o estado de Goiás e o Distrito Federal. ACTA Geográfica, 8:40-55.

Climate-Data.ORG (2017) Acompanhamento do clima. Available at: https://pt.climate-data.org/america-do-sul/brasil/goias/ inaciolandia-312849/. Accessed on: September $28^{\text {th }}, 2017$.

CONAB - Companhia Nacional de Abastecimento (2017) Acompanhamento de safra brasileiro - grãos: Décimo segundo levantamento, setembro 2017 - safra 2016/2017. Available at: <https://www.conab.gov.br/OlalaCMS/uploads/arquivos/ 17_09_12_10_14_36_boletim_graos_setembro_2017.pdf $>$. Accessed on: September $28^{\text {th }}, 2017$

Conte O, Flores JPC, Cassol LC, Anghinoni I, Carvalho PCF, Levien R \& Wesp CL (2011) Evolução de atributos físicos de solo em sistema de integração lavoura pecuária. Pesquisa Agropecuária Brasileira, 46:1301-1309.

Costa NR, Andreotti M, Gameiro RA, Pariz CM, Buzetti S \& Lopes KSM (2012) Adubação nitrogenada no consórcio de milho com duas espécies de braquiária em sistema plantio direto. Revista Pesquisa Agropecuária Brasileira, 47:1038-1047.

Crusciol CAC \& Borghi E (2007) Consórcio de milho com braquiária: produção de forragem e palhada para o plantio direto. Revista Plantio Direto, 16:10-14.

Didonet AD, Rodrigues O, Mario JL \& Ide F (2002) Efeito da radiação solar e temperatura na definição do número de grãos em milho. Pesquisa Agropecuária Brasileira, 37:933-938.

Embrapa - Empresa Brasileira de Pesquisa Agropecuária (1999) Sistema brasileiro de classificação de solos. Rio de janeiro, Embrapa. 412p.

Fancelli AL \& Dourado Neto D (2000) Ecofisiologia e fenologia. In: Fancelli AL \& Dourado Neto D (Eds.) Produção de milho. Piracicaba, Agropecuária. p.21-54.

Feitosa IL, Aker AM, Vargas LA, Cipriani H, Marcolan AL \& Passos AMA (2016) Crescimento de milho com diferentes arranjos espaciais em sistema ILPF na Amazônia Ocidental. In: $31^{\circ}$ Congresso Nacional de Milho e Sorgo, Bento Gonçalves. Anais, Associação Brasileira de Milho e Sorgo. p.998-1000.

Franzluebbers AJ (2007) Integrated crop livestock systems in the southeastern USA. Agronomy Journal, 99:361 372.

Freitas RJ, Nascente AS \& Santos FLS (2013) População de plantas de milho consorciado com Urochloa ruziziensis. Pesquisa Agropecuária Tropical, 43:79-87.

Gimenes MJ, Victoria Filho R, Prado EP, Pogetto MHFAD \& Christovam RS (2008) Interferência de espécies forrageiras em consórcio com a cultura do milho. Revista da FZVA, 15:61-76.

Rede Fomento ILPF (2016) Integração Lavoura-Pecuária-floresta. Available at: <https://www.redeilpf.org.br/arquivos/2016cpamt-ilpf-em-numeros.pdf $>$. Accessed on: September $28^{\text {th }}$, 2017.

Kuemmel B (2003) Theoretical investigation of the effects of field margins and hedges on crops yields. Agriculture, Ecossystems \& Environment, 95:387-392.

Ohland RAA (2005) Culturas de Cobertura do Solo e Adubação Nitrogenada no Milho em Plantio Direto. Ciência e Agrotecnologia, 29:538-544.

Porfirio-da-Silva V, Moraes A, Moletta JL, Pelissari A, Dieckow J \& Oliveira EB (2015) Produtividade do milho em um sistema silviagrícola nos campos gerais, PR. Scientia Agraria, 16:27-32.
Santos HP, Fontaneli RS, Spera ST \& Dreon G (2013) Conversão e balanço energético de sistemas de produção com integração lavoura-pecuária, sob plantio direto. Agrária - Revista Brasileira de Ciências Agrárias. 8:1-7.

Silva EF, Lourente EPR, Marchetti ME, Mercante FM, Ferreira AKT \& Fujii GC (2011) Frações lábeis e recalcitrantes de matéria orgânica em solos sob integração lavoura-pecuária. Pesquisa Agropecuária Brasileira, 46:1321-1331.

Silva DS, Amado TJC, Ferreira AO, Assmann JM, Anghinoni I \& Carvalho PCF (2014) Soil carbon indices as affected by 10 years of integrated crop-livestock production with different pasture grazing intensities in Southern Brazil. Agriculture, Ecosystems and Environment, 19:60-69.

Simão EP, Gontijo Neto MM, Queiroz LR, Alvarenga RC, Viana MCM \& Silva IHS (2012) Efeito da distância entre as linhas da cultura e o renque de eucalipto sobre o rendimento de grãos e forragem do consórcio milho mais braquiária ruziziensis. In: $29^{\circ}$ Congresso Nacional de Milho e Sorgo, Águas de Lindóia. Anais, IAC. p.2262-2267.

Souza ED, Costa SEVGA, Anghinoni I, Carvalho PCF, Andrigueti M \& Caio E (2009) Estoque de carbono orgânico e de nitrogênio no solo em sistema de integração lavoura-pecuária em plantio direto, submetido a intensidades de pastejo. Revista Brasileira de Ciência do Solo, 33:1829-1836.

Wendling IJ, Gontijo Neto MM, Simao EP, Santos EA, Cecon CF \& Borghi E (2014) Produtividade de consórcio milho e braquiárias em sistema de integração lavoura-pecuária-floresta, na Região do Cerrado brasileiro. In: $30^{\circ}$ Congresso Nacional de Milho e Sorgo, Salvador. Anais, Associação Brasileira de Milho e Sorgo. Anais, sem paginação.

Rev. Ceres, Viçosa, v. 67, n.3, p. 176-180, may/jun, 2020 